\title{
Does change in blood pressure predict heart disease?
}

\author{
ALBERT HOFMAN, MANNING FEINLEIB, ROBERT J GARRISON, ABRAHAM VAN LAAR
}

\begin{abstract}
Whether a change in blood pressure is related to the occurrence of cardiovascular disease, independent of blood pressure level, was investigated using data collected in the Framingham heart study on 5209 subjects. The follow up period of 26 years was divided into a first period of 12 years in which the blood pressure change was computed for each individual and a subsequent period of 14 years in which the risk of cardiovascular disease was determined. Blood pressure change was positively related to risk of cardiovascular disease. This association remained when blood pressure level at the start of the study was taken into account but disappeared when the level attained after the first 12 years was taken into consideration. For the clinician this suggests that the decision to treat high blood pressure is best guided by the actual level of pressure and not by its long term trend in the past.
\end{abstract}

\section{Introduction}

Although many studies have shown a strong relation between the level of blood pressure and atherosclerotic diseases, ${ }^{1-5}$ it is not known whether it is the actual level of blood pressure or the rate of increase of blood pressure over time that is the most important predictor of cardiovascular events.

Department of Epidemiology, Erasmus University Medical School, Rotterdam, The Netherlands

ALBERT HOFMAN, MD, PHD, lecturer in epidemiology

ABRAHAM VAN LAAR, systems analyst

Epidemiology and Biometry Program, Division of Heart and

Vascular Diseases, National Heart, Lung and Blood Institute,

National Institutes of Health, Bethesda, Maryland, USA

MANNING FEINLEIB, MD, DRPH(USA), director

ROBERT J GARRISON, MS, chief of biometrics research branch

Correspondence and reprint requests to: Dr A Hofman.
We studied the relation between rise of blood pressure and the occurrence of cardiovascular events, coronary heart disease, and death from all causes using data collected in the Framingham heart study. The yearly increase of blood pressure was obtained for each individual from five to seven blood pressure readings over a 12 year observation period and related to incidence of cardiovascular events, coronary disease, and death from all causes in a subsequent 14 year period of follow up.

\section{Subjects and methods}

In the Framingham heart study a cohort of residents of Framingham, Massachusetts, USA, aged 30-62 years at the start of the study, has been followed for 26 years since 1948, as described in detail elsewhere. ${ }^{5}$ In brief, a sample of 3074 men and 3433 women was invited, of whom 2024 men and 2445 women took part in the study; 740 volunteers ( $312 \mathrm{men}$ ) were added to the respondents, so that the study cohort comprised 2336 men and 2873 women. They were examined every two years and follow up data were obtained over a period of 26 years for essentially the entire cohort. Blood pressure was measured by a doctor on the subject's left arm while sitting. Diastolic pressure was based on the fifth Korotkoff sound. A standard mercury sphygmomanometer with a $14 \mathrm{~cm}$ cuff was used.

\section{DIAGNOSTIC CRITERIA}

Diagnostic criteria for the diseases under study have been given elsewhere. ${ }^{5}$ Here we consider only all cardiovascular events (including coronary heart disease, intermittent claudication, congestive heart failure, cerebrovascular accidents), coronary heart disease (excluding angina pectoris), and death from all causes. All events were reviewed by a panel of investigators.

\section{OBSERVATION PERIOD}

For this analysis the 26 years of follow up were divided into an observation period of 12 years on which the rate of increase of blood pressure for each individual was computed and a subsequent period of 14 years during which the incidence of cardiovascular events, coronary 
disease, and death from all causes was determined. This gives estimates of the 14 year risk of these events. The men and women in the cohort were aged 42-74 years at the start of the 14 year follow up period.

\section{ELIGIBILITY FOR ANALYSIS}

Eligible for this analysis were the 1460 men and 1890 women who attended the seventh biennial examination (12 years after entry in the study), were free of cardiovascular disease at that time, were not taking antihypertensive drugs, and had at least five (out of a maximum of seven) readings during the observation period of 12 years. Of the original cohort, 876 men were not eligible for one (or more) of the following reasons: 253 died (149 of a cardiovascular event) and 430 suffered a cardiovascular event before the seventh biennial examination, 136 were taking antihypertensive drugs at the seventh biennial examination, and 296 had fewer than five blood pressure readings. Similarly, 983 women were not eligible: 152 died (63 of a cardiovascular event) and 267 had a cardiovascular event, 356 were taking antihypertensive drugs, and 284 had fewer than five blood pressure readings.

\section{DATA ANALYSIS}

The rate of increase in blood pressure was determined by least squares regression of pressure on time for each individual. The slope obtained in this regression serves as an estimate of the yearly increase of pressure.

We analysed the predictive value of the rise in blood pressure for cardiovascular disease conditional on initial pressure and conditional on attained pressure. Initial and attained levels were recorded at the beginning and the end respectively of the 12 year observation period over which the yearly increase of blood pressure was obtained. Within each of four strata of initial and attained blood pressure readings the subjects were divided according to the median of the yearly change of pressure (medians are given in table I). We compared the proportions of subjects suffering a cardiovascular event among those with a small increase in blood pressure (below the median) and those with a large

\begin{tabular}{|c|c|c|c|c|}
\hline \multirow[t]{2}{*}{$\begin{array}{l}\text { Systolic blood } \\
\text { pressure }\end{array}$} & \multicolumn{2}{|c|}{$\operatorname{Men}(n=1460)$} & \multicolumn{2}{|c|}{ Women $(n=1890)$} \\
\hline & \multicolumn{2}{|c|}{ Initial level } & & \\
\hline \multirow[t]{2}{*}{$\begin{array}{l}\leqslant 119 \\
120-129 \\
130-139 \\
\geqslant 140\end{array}$} & $\begin{array}{r}0.64 \\
0.22 \\
0.20 \\
-0.26\end{array}$ & $\begin{array}{l}(291) \\
(358) \\
(383) \\
(428)\end{array}$ & $\begin{array}{l}0.76 \\
0.43 \\
0.41 \\
0.07\end{array}$ & $\begin{array}{l}(518) \\
(473) \\
(387) \\
(512)\end{array}$ \\
\hline & \multicolumn{2}{|c|}{ Attained level } & & \\
\hline $\begin{array}{l}\leqslant 119 \\
120-129 \\
130-139 \\
\geqslant 140\end{array}$ & $\begin{array}{r}-0.54 \\
-0.06 \\
0.21 \\
1.14\end{array}$ & $\begin{array}{l}(317) \\
(316) \\
(317) \\
(510)\end{array}$ & $\begin{array}{r}-0.29 \\
0.17 \\
0.64 \\
1.32\end{array}$ & $\begin{array}{l}(445) \\
(379) \\
(372) \\
(694)\end{array}$ \\
\hline
\end{tabular}

increase (above the median). In addition, we performed logistic regression ${ }^{6}$ with cardiovascular events, coronary disease, or death from all causes as the outcome variable and the yearly change of blood pressure and initial or attained level of pressure as independent variables. We added potential confounders of the relation between blood pressure change and cardiovascular disease to the model, notably age (years), total serum cholesterol ( $\mathrm{mmol} / \mathrm{l})$, obesity (Framingham relative weight), diabetes mellitus (yes, no), and cigarette smoking (yes, no). These covariates were measured at the start of the 14 year follow up (together with the attained level of blood pressure).

\section{Results}

The yearly rise in systolic blood pressure was positively associated with cardiovascular events, coronary disease, and death from all causes. When the initial level of pressure was taken into account this association remained (table II). Within each category of initial pressure subjects with a large increase in blood pressure suffered considerably more cardiovascular events than those with a small increase (fig 1). After adjustment for other potential predictors of disease risk the yearly rise of systolic blood pressure remained associated with cardiovascular events, coronary disease, and death from all causes in both men and women (table III). The interaction between age and change of blood pressure in the logistic model was not significantly different from zero. We obtained essentially the same results for diastolic pressure.

When instead of initial level the attained level of systolic blood pressure was taken into account the increase in systolic pressure was not related to disease risk (table II). Within each stratum of attained systolic pressure subjects with a large increase in blood pressure before they reached the attained level experienced about the same number of cardiovascular events as those with a small rise (fig 2). A separate analysis showed this also to be the case for those with an

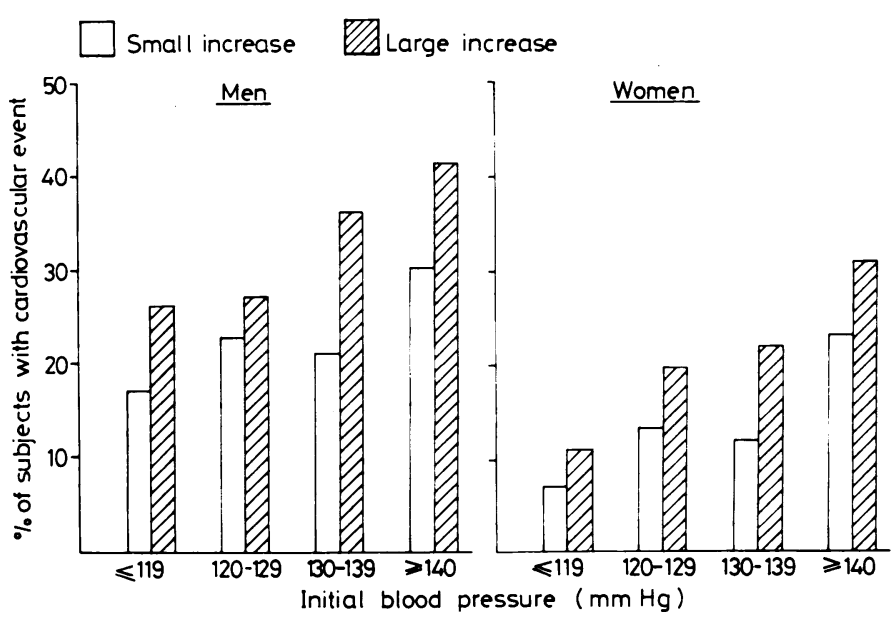

FIG 1-Proportion of small increasers and large increasers suffering a cardiovascular event conditional on initial blood pressure.

TABLE II-Percentage of events among subjects with small increases in blood pressure $(S)$ and those with large increases $(L)$ according to initial and attained systolic blood pressures $(\mathrm{mm} \mathrm{Hg})$. (Percentage of fatal cardiovascular events are given in parentheses)

\begin{tabular}{|c|c|c|c|c|c|c|c|c|c|c|c|c|}
\hline \multirow{3}{*}{$\begin{array}{l}\text { Systolic } \\
\text { blood pressure }\end{array}$} & \multicolumn{6}{|c|}{$\operatorname{Men}(n=1460)$} & \multicolumn{6}{|c|}{ Women $(n=1890)$} \\
\hline & \multicolumn{2}{|c|}{$\begin{array}{c}\text { Cardiovascular } \\
\text { disease* }\end{array}$} & \multicolumn{2}{|c|}{$\begin{array}{c}\text { Coronary } \\
\text { heart disease } \dagger\end{array}$} & \multicolumn{2}{|c|}{ Death } & \multicolumn{2}{|c|}{$\begin{array}{l}\text { Cardiovascular } \\
\text { disease* }\end{array}$} & \multicolumn{2}{|c|}{$\begin{array}{c}\text { Coronary } \\
\text { heart disease } †\end{array}$} & \multicolumn{2}{|c|}{ Death } \\
\hline & s & $\mathrm{L}$ & $s$ & $\mathrm{~L}$ & $\mathbf{s}$ & $\mathrm{L}$ & $\mathbf{s}$ & $\mathbf{L}$ & $\mathbf{s}$ & $\mathbf{L}$ & $s$ & $\mathrm{~L}$ \\
\hline \multicolumn{13}{|c|}{ Initial level } \\
\hline $\begin{array}{l}\leq 119 \\
120-129 \\
130-139 \\
\geqslant 140\end{array}$ & $\begin{array}{l}7 \\
23 \\
21 \\
30\end{array}$ & $\begin{array}{l}16 \\
27 \\
36 \\
41\end{array}$ & $\begin{array}{l}8 \\
13 \\
13 \\
18\end{array}$ & $\begin{array}{l}12 \\
16 \\
20 \\
22\end{array}$ & $\begin{array}{l}16(5) \\
13(7) \\
16(5) \\
24(12)\end{array}$ & $\begin{array}{l}19(9) \\
25(10) \\
25(9) \\
31(18)\end{array}$ & $\begin{array}{r}7 \\
13 \\
12 \\
23\end{array}$ & $\begin{array}{l}11 \\
19 \\
22 \\
30\end{array}$ & $\begin{array}{r}2 \\
3 \\
5 \\
10\end{array}$ & $\begin{array}{r}4 \\
8 \\
6 \\
11\end{array}$ & $\begin{array}{r}6(1) \\
7(1) \\
11(3) \\
24(9)\end{array}$ & $\begin{array}{l}11(3) \\
12(5) \\
125(5) \\
25(14)\end{array}$ \\
\hline $\begin{array}{l}\leq 119 \\
120-129 \\
130-139 \\
\geqslant 140\end{array}$ & $\begin{array}{l}23 \\
23 \\
23 \\
41\end{array}$ & $\begin{array}{l}15 \\
21 \\
23 \\
42\end{array}$ & $\begin{array}{l}13 \\
14 \\
14 \\
25\end{array}$ & $\begin{array}{l}12 \\
14 \\
11 \\
21\end{array}$ & $\begin{aligned} & \text { Attai } \\
& 7(7) \\
& 21(9) \\
& 18(7) \\
& 26(13)\end{aligned}$ & $\begin{array}{l}\text { level } \\
12(0) \\
17(6) \\
23(6) \\
34(15)\end{array}$ & $\begin{array}{r}9 \\
13 \\
15 \\
28\end{array}$ & $\begin{array}{l}10 \\
12 \\
12 \\
26\end{array}$ & $\begin{array}{r}2 \\
4 \\
6 \\
11\end{array}$ & $\begin{array}{r}2 \\
3 \\
5 \\
11\end{array}$ & $\begin{array}{r}10(2) \\
7(2) \\
12(3) \\
24(12)\end{array}$ & $\begin{array}{r}7(1) \\
9(3) \\
12(3) \\
17(8)\end{array}$ \\
\hline
\end{tabular}

* All cardiovascular diseases, including coronary heart disease, angina pectoris, intermittent claudication, congestive heart failure, cerebrovascular accidents.

+ Coronary heart disease, not including angina pectoris. 
attained systolic blood pressure of $160 \mathrm{~mm} \mathrm{Hg}$ or over. Logistic regression with the attained level in the model gave coefficients which were not significantly different from zero, although they were all negative (table III). This was the case for systolic and diastolic pressure.

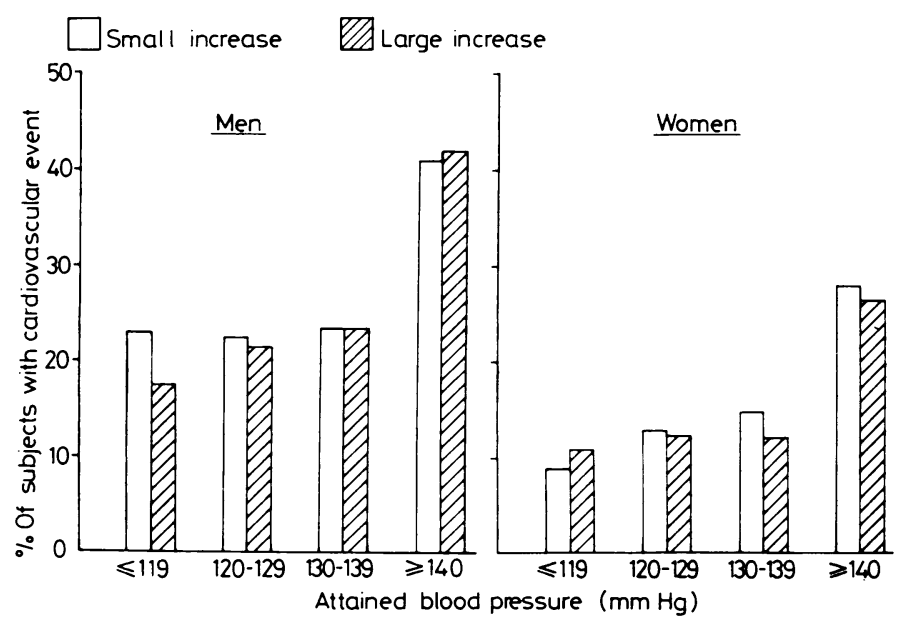

FIG 2-Proportion of small increasers and large increasers suffering a cardiovascular event conditional on attained blood pressure.

TABLE III-Coefficients of logistic regression* of events on rate of increase in systolic blood pressure conditional on initial and attained systolic pressures

\begin{tabular}{|c|c|c|c|c|c|c|}
\hline \multirow[t]{2}{*}{ Event } & \multicolumn{3}{|c|}{$\operatorname{Men}(n=1427) \dagger$} & \multicolumn{3}{|c|}{ Women $(n=1760)$} \\
\hline & b & SEb & $\mathrm{p}_{2}$ & b & $\mathrm{SEb}$ & $\mathbf{p}_{2}$ \\
\hline \multicolumn{7}{|c|}{ Conditional on initial level } \\
\hline $\begin{array}{l}\text { Cardiovascular disease }+ \\
\text { Coronary heart disease } \\
\text { Death }\end{array}$ & $\begin{array}{l}0 \cdot 150 \\
0 \cdot 129 \\
0 \cdot 177\end{array}$ & $\begin{array}{l}0.046 \\
0.056 \\
0.051\end{array}$ & $\begin{array}{l}0.001 \\
0 \cdot 018 \\
0.001\end{array}$ & $\begin{array}{l}0 \cdot 190 \\
0 \cdot 164 \\
0 \cdot 128\end{array}$ & $\begin{array}{l}0.048 \\
0.071 \\
0.052\end{array}$ & $\begin{array}{l}0.0002 \\
0.022 \\
0.015\end{array}$ \\
\hline \multicolumn{7}{|c|}{ Conditional on attained level } \\
\hline $\begin{array}{l}\text { Cardiovascular disease } \\
\text { Coronary heart disease } \\
\text { Death }\end{array}$ & $\begin{array}{l}-0.074 \\
-0.082 \\
-0.049\end{array}$ & $\begin{array}{l}0.057 \\
0.067 \\
0.062\end{array}$ & $\begin{array}{l}0 \cdot 194 \\
0 \cdot 219 \\
0 \cdot 435\end{array}$ & $\begin{array}{l}-0.042 \\
-0 \cdot 125 \\
-0.109\end{array}$ & $\begin{array}{l}0.056 \\
0.081 \\
0.060\end{array}$ & $\begin{array}{l}0.453 \\
0 \cdot 126 \\
0.070\end{array}$ \\
\hline
\end{tabular}

$\mathrm{SE}=$ Standard error

* Adjusted for total serum cholesterol, smoking, diabetes mellitus, Framingham relative weight, and age.

† Slightly different from table I owing to missing values of covariates.

† All cardiovascular diseases, including coronary heart disease, angina pectoris, intermittent claudication, congestive heart failure, and cerebrovascular accidents.

\section{Discussion}

The findings in this study suggest that blood pressure rise predicts cardiovascular disease conditional on initial level of blood pressure, but not on attained level. In other words, given a certain level of blood pressure, what matters is where you go to, and not where you came from (fig 3). This seems paradoxical, but it has to be borne in mind that the relation between

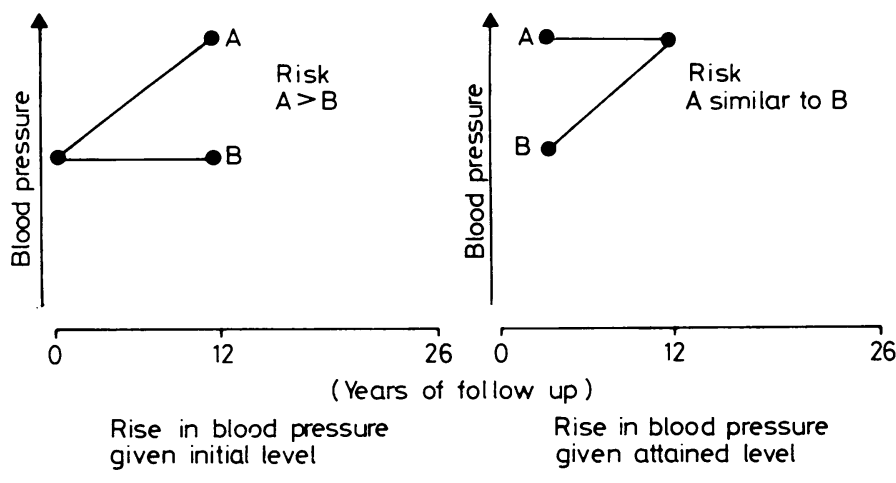

FIG 3-Diagram of observations in this study. blood pressure rise and cardiovascular disease, given initial level, might simply reflect the change of level over time. Contrary to what has been suggested ${ }^{78}$ we cannot infer from this that change in blood pressure by itself contributes to cardiovascular risk. A true independent effect of blood pressure change should manifest itself conditional on attained level, and we found no evidence of such an effect.

Blood pressure change was estimated by linear regression of blood pressure on time. This entailed making the assumption, undoubtedly unwarranted in some subjects, of a linear increase in blood pressure over time. The inadequacy of the model might dilute a true relation between rise of pressure and disease risk and therefore the true coefficients conditional on attained level might be (more) negative. Since the study population was between 42 and 74 years old and free of cardiovascular disease at the start of follow up our analysis does not address the question whether blood pressure change earlier in life plays an important role in determining cardiovascular risk. Furthermore, we consider here only the long term change in pressure and the current findings reflect average trends in the population. A separate analysis showed that the variability of blood pressure over the 12 year observation period, as measured by the residuals of individual linear regression of pressure on time, was not a predictor of cardiovascular disease, whether conditional on initial or attained level. This confirms a previous report from the Framingham study. ${ }^{9}$

From a clinician's viewpoint these findings suggest that decisions concerning the treatment of "borderline"or high blood pressure might be best guided by the actual level of pressure and not by its trend in the past. For example, the risk for a 50 year old man with a systolic pressure of $160 \mathrm{~mm} \mathrm{Hg}$ is similar whether his pressure has risen from $130 \mathrm{~mm} \mathrm{Hg}$ or has remained at $160 \mathrm{~mm} \mathrm{Hg}$ over the past 12 years.

From a public health viewpoint the finding that the rate of change in blood pressure, given a certain initial level, predicts occurrence of cardiovascular disease indicates that there might be merit in preventing blood pressure from rising. This seems to apply to the whole range of initial levels and underscores the idea that preventive measures affecting the population as a whole, ${ }^{10}$ as well as "high risk" groups, might be effective.

This study was supported in part under contract N01-HV-52971 with the National Institutes of Health. A $\mathrm{H}$ was supported by a grant from the Netherlands Organisation for Pure Scientific Research. We acknowledge the contributions of Professor $\mathrm{H} \mathrm{A}$ Valkenburg and Dr J P Vandenbroucke.

\section{References}

1 Society of Actuaries. Build and blood pressure study. Chicago: Society of Actuaries, 1959.

2 Stamler J, Lindberg HA, Berkson DM, Shaffer A, Miller W, Poindexter A. Prevalence and incidence of coronary heart disease in strata of the labor force of a Chicago industrial corporation. 7 Chronic Dis 1960;11: 405-17.

${ }^{3}$ Keys A, Taylor HL, Blackburn H, Brozek J, Anderson JT, Simonson E. Mortality and coronary heart disease among men studied for 23 years. Arch Intern Med 1971;128:201-14.

4 Pooling project research group. Relationship of blood pressure, serum cholesterol, smoking habit, relative weight and ECG abnormalities to incidence of major coronary events. $\mathcal{F}$ Chronic Dis 1978;31:210-306.

${ }^{5}$ Dawber TR. The Framingham study. Cambridge: Harvard University Press, 1980

6 Lee ET. A computer program for linear logistic regression analysis. Comput Programs Biomed 1974;4:80-92.

7 Woodbury MA, Mandon KG, Stallard P. Longitudinal analysis of the dynamics and risk of coronary heart disease in the Framingham study. Biometrics 1979;35:575-85.

${ }^{8}$ Farchi G, Capocaccia R, Verdecchia A, Menotti A, Keys A. Risk factor changes and coronary heart disease in an observational study. Int $\mathfrak{f}$ Epidemiol 1981;10:31-40.

${ }^{9}$ Kannel WB, Sorlie P, Gordon T. Labile hypertension: a faulty concept ? The Framingham study. Circulation 1980;61:1183-7.

${ }^{10}$ Rose G. Strategy of prevention: lessons from cardiovascular disease. $\mathrm{Br}$ Med f 1981 ;282:1847-51. 